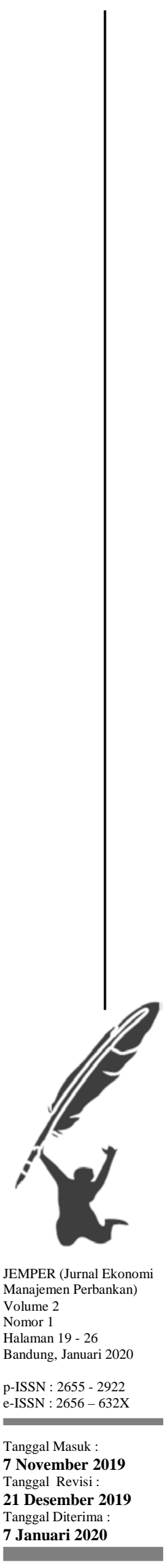

JEMPER(Jurnal Ekonomi Manajemen Perbankan)

http://jurnal.usbypkp.ac.id/index.php/jemper

\title{
PENGARUH LAPORAN ARUS KAS TERHADAP TINGKAT LIKUIDITAS \\ (Studi Kasus Pada Lembaga Pembiayaan di Bursa Efek Indonesia 2013-2017)
}

\author{
Yogi Atmadijaya ${ }^{1}$ \\ Universitas Sangga Buana YPKP Bandung \\ atmadijayayogi@gmail.com \\ Hilda Purnamawati ${ }^{2}$ \\ Universitas Sangga Buana YPKP Bandung \\ hildapurnamawati@yahoo.com \\ Iyan Sukiman ${ }^{3}$ \\ Universitas Sangga Buana YPKP Bandung \\ iyan.sukiman@gmail.com
}

\begin{abstract}
The research method used is a quantitative method with cuantitavie descriptive. The population in this study were all publicly listed companies listed on the Indonesia Stock Exchange in 2013-2017, the sampling technique used was purposive sampling and the samples taken were 12 financial institutions. The data analysis technique in this study is panel data regression analysis usingEviews. The test results show that in 2013-2017 the development of cash flows in 12 financial institutions fluctuated, with the highest average occurring in 2015. The development of the level of liquidity in 12 financial institutions tended to fluctuate with the highest liquidity level was 2014 Danasupra Erapacific Tbk. Partially cash flows from operating activities have a significant effect on the level of liquidity of financial institutions in 2013-2017. Partially the cash flows from investment activities have no significant effect on the level of liquidity of financial institutions in 2013-2017. Partially cash flows from funding activities have a significant effect on the level of liquidity of financial institutions in 2013-2017. Simultaneously, cash flows that feel from operating, investing and funding activities have a significant effect on the level of liquidity of financial institutions in 2013-2017 with a magnitude of influence of $72.7 \%$
\end{abstract}

Keywords : Operating Cash Flow, Investment Cash Flow, Funding Cash Flow, Liquidity.

\begin{abstract}
Abstrak
Metode penelitian yang digunakan adalah metode kuantitatif dengan pendekatan penelitian deskriftif dan asosiatif. Populasi dalam penelitian ini adalah seluruh perusahaan go public yang terdaftar di Bursa Efek Indonesiatahun 2013-2017, teknik sampling yang digunakan purposive sampling dan sampel yang diambil sebanyak 12 lembaga pembiayaan. Teknik analisis data dalam penelitian ini adalah analisis regresi data panel dengan menggunakan Eviews. Hasil pengujian menunjukkan bahwa pada tahun 2013-2017 perkembangan arus kas pada 12 lembaga pembiayaan berfluktuatif, dengan rata-rata tertinggi terjadi pada tahun 2015. Perkembangan tingkat likuiditas pada 12 lembaga pembiayaan cenderung mengalami fluktuatif dengan tingkat likuiditas tertinggi adalah Danasupra Erapacific Tbk pada tahun 2014. Secara parsial arus kas yang berasal dari kegiatan operasi berpengaruh signifikan terhadap tingkat likuiditas lembaga pembiayaan tahun 2013-2017. Secara parsial arus kas yang berasal dari kegiatan investasitidak berpengaruh signifikan terhadap tingkat likuiditas lembaga pembiayaan tahun 2013-2017. Secara parsial arus kas yang berasal dari kegiatan pendanaan berpengaruh signifikan terhadap tingkat likuiditas lembaga pembiayaan tahun 2013-2017. Secara simultan arus kas yang berasa dari kegiatan operasi, investasi dan pendanaan berpengaruh signifikan terhadap tingkat likuiditas lembaga pembiayaan tahun 2013-2017 dengan besarnya pengaruh sebesar 72,7\%.
\end{abstract}

Kata Kunci : Arus Kas Operasi, Arus Kas Investasi, Arus Kas Pendanaan, Likuiditas 


\section{PENDAHULUAN}

Dalam menjalankan kegiatan usahanya, perusahaan harus menyusun laporan keuangan yang menggambarkan segala jenis transaksi yang terjadi di dalam perusahaan. Dengan menganalisis laporan keuangan, pihak manajemen dapat menentukan langkah nyata agar perusahaan berjalan sesuai dengan yang diinginkan.

Semakin besar jumlah kas yang akan dimiliki oleh perusahaan akan semakin tinggi pula tingkat likuiditasnya. Apabila perusahaan yang mempunyai tingkat likuiditas yang tinggi mencerminkan adanya over investment dalam kas dan berarti perusahaan kurang efektif dalam mengelola kas karena kas tidak diputar, sebaliknya jumlah kas yang relatif kecil akan memperoleh tingkat perputaran kas yang tinggi. "laporan sumber dan penggunaan kas disusun untuk menunjukan perubahan kas selama satu periode dan memberikan alasan mengenai perubahan kas tersebut dengan menunjukan dari mana sumber-sumber kas dan pengunaannya” S. Munawir (2004;157).

Laporan arus kas merupakan laporan yang sangat bermanfaat dan penting bagi perusahaan, dimana dalam kegiatan operasinya pasti memerlukan kas untuk menjalankan usaha, melunasi kewajiban dan membagikan deviden kepada para pemegang saham, dengan menganalisis laporan keuangan maka para pemakai laporan keuangan dapat mengetahui arus kas masuk dan keluar, selain itu perusahaan dapat memprediksi jumah kas masuk dan keluar untuk waktu yang akan datang.

Kas sangat berperan dalam menentukan kelancaran kegiatan perusahaan, oleh karena itu sumber dan penggunaan kas harus direncanakan dan diawasi dengan baik..Berkaitan dengan likuiditas perusahaan, arus kas memberikan informasi bagi manajer mengenai kesanggupan perusahaan menyediakan kas untuk membayar kewajiban jangka pendek.

Ketua APPI Suwandi Wiratno menyebut dalam bebeberapa tahun ke belakang, beberapa pemain memang mengalami perlambatan bisnis. Kondisi ini berimbas pada kesulitan likuiditas yang dialami sejumlah perusahaan. Gambar grafik perkembangan arus kas yang berasal dari aktivitas operasi dan tingkat likuiditas pada lembaga pembiayaan selama tahun 2013-2017 sebagai berikut :

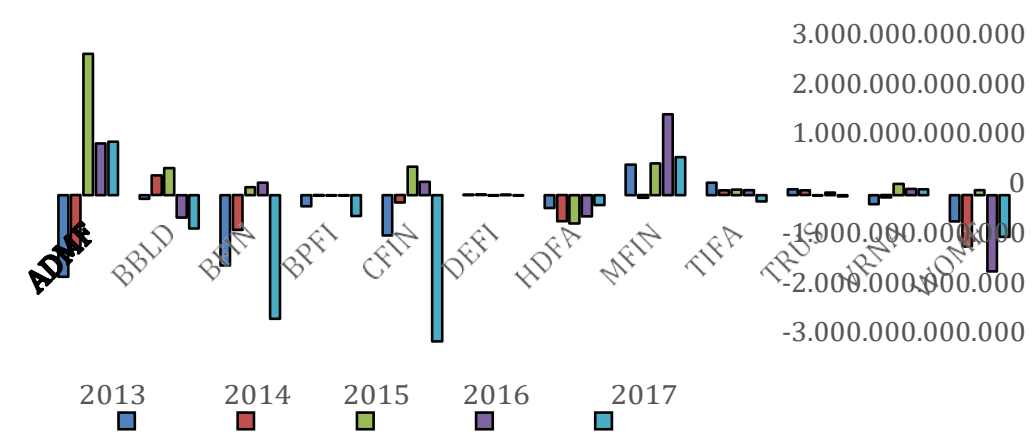

Gambar 1

Perkembangan Laporan Kas Lembaga Pembiayaan Tahun 2013-2017

Sumber: Data sekunder diolah, 2019 


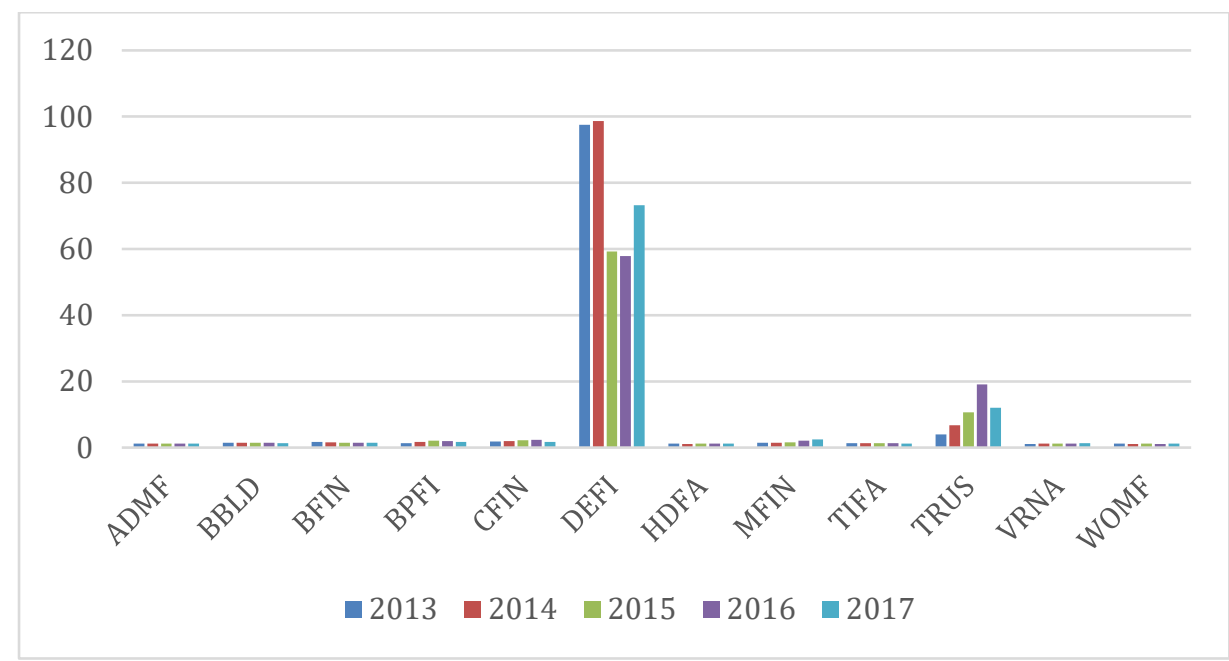

Gambar 2

Tingkat Likuiditas pada Lembaga Pembiayaan Tahun 2013-2017

Sumber: Data sekunder diolah, 2019

Dari data diatas dapat diketahui bahwa terjadi laporan arus kas operasi yang fluktuatif , yaitu sebuah kondisi atau keadaan yang tidak stabil, yang menunjukkan gejala yang tidak tetap dan selalu berubah-ubah. Oleh karena itu perusahaan dituntut agar mampu mengelola dana yang ada untuk dipergunakan membiayai segala jenis kegiatannya dan harus hati-hati dalam menangani masalah keuangan, khususnya dalam pengelolaan sumber dan penggunaan kas.Kas merupakan modal kerja yang paling likuid sehingga dengan ketersediaan kas yang cukup dapat membantu perusahaan dalam memenuhi likuiditasnya.

\section{LITERATUR}

\section{Hasil Penelitian Terdahulu}

Berdasarkan penelitian Nurmiati (2016) dengan judul "Pengaruh Arus Kas Operasi Terhadap Likuiditas Perusahaan Farmasi Yang Terdaftar Di Bursa Efek Indonesia 2014 2016 dimana hasil penelitian menunjukkan bahwa arus kas operasi berpengaruh signifikan terhadap tingkat likuiditas.Berdasarkan penelitian Utami, Desi Sri (2013) dengan judul "Pengaruh Arus Kas Terhadap Tingkat Likuiditas Keuangan Perusahaan PT PLN(Persero) 2002 - 2011 menunjukkan arus kas mempunyai pengaruh positif dan signifikan terhadap tingkat likuiditas.

\section{Laporan Arus Kas}

Menurut Skousen dkk (2009 : 284) Laporan arus kas itu sendiri didefinisikan sebagai berikut

"Laporan arus kas (Statement Of Cash Flow) adalah laporan keuangan yang melaporkan jumlah kas yang diterima dan dibayar oleh suatu perusahaan selama periode tertentu”.

\section{Likuiditas}

Mardiyanto (2009:54) ialah : "Likuiditas mengukur kemampuan perusahaan untuk melunasi kewajiban (utang) jangka pendek tepat pada waktunya, termasuk melunasi bagian utang jangkapanjang yang jatuh tempo pada tahun bersangkutan.Rasio yang digunakan untuk mengukur tingkat likuiditas perusahaan, salah satunya adalah Rasio lancar (Current Ratio). 


\section{METODE PENELITIAN}

Adapun metode yang penulis gunakan dalam penelitian menggunakan metode kuantitatif dengan pendekatan penelitian deskriptif dan asosiatif. Jenis data penelitian adalah data kuantitatif, data tersebut diperoleh dari laporan keuangan perusahaan lembaga pembiayaan yang dipublikasikan setiap tahunnya oleh Bursa Efek Indonesia (BEI) periode tahun 2013 2017

Populasi dalam penelitian ini adalah seluruh perusahaan go public yang terdaftar di Bursa Efek Indonesia tahun 2013-2017, teknik sampling yang digunakan purposive sampling dan sampel yang diambil sebanyak 12 lembaga pembiayaan yang terdaftar di Bursa Efek Indonesia tahun 2013-2017 .Metode analisis data yang digunakan adalah regresi data panel, dimana akan dilakukan estimasi data panel yang terdiri dari 3 model regresi yaitu Common Effect, FixedEffect dan Random Effect dengan sebelumnya diuji terlebih dahulu dengan3 uji model regresi yaitu Ujichow, Uji Hausman dan Uji Lagrange Multiplier.Lalu dilakukan Uji Asumsi klasik untuk mengetahui ada tidaknya pelanggaran asumsi-asumsi klasik. Pengujian asumsi klasik meliputi uji normalitas,uji multikolinearitas,dan uji heteroskedastisitas. Pengujian hipotesis dalam penelitian ini menggunakan beberapa teknik analisis, yaitu uji t dan uji F. Untuk mengetahui seberapa besar variabel X menjelaskan perubahan atau pergerakan variabel Y maka dilakukan uji koefisien determinasi (R2).

Pengujian Hipotesis :

1) Uji Signifikansi Parsial (Uji StatistikT)

2) Uji Signifikansi Simultan (Uji Statisitk F)

\section{HASIL DAN PEMBAHASAN}

\section{Analisis Deskriptif}

Pada penelitian ini.. perusahaan yang memenuhi kriteria dalam penelitian ini adalah sebanyak 12 lembaga pembiayaan tahun 2013-2017. Di bawah ini disajikan perusahaan yang menjadi sampel dalam penelitian :

\section{Tabel 1}

Perusahaan yang Menjadi Sampel Penelitian

\begin{tabular}{ccc}
\hline No. & Kode Perusahaan & Nama Perusahaan \\
\hline 1. & ADMF & Adira Dinamika Multi Finance Tbk \\
2. & BBLD & Buana Finance Tbk \\
3. & BFIN & BFI Finance Indonesia Tbk \\
4. & BPFI & Batavia Prosperindo Finance Tbk \\
5. & CFIN & Clipan Finance Indonesia Tbk \\
6. & DEFI & Danasupra Erapacific Tbk \\
7. & HDFA & Radana Bhaskara Finance Tbk \\
8. & MFIN & Mandala Multifinance Tbk \\
9. & TIFA & Tifa Finance Tbk \\
10. & TRUS & Trust Finance Indonesia Tbk \\
11. & VRNA & Verena Multifinance Tbk \\
12. & WOMF & Wahana Ottomitra Multiartha Tbk \\
\hline
\end{tabular}

Sumber : Bursa Efek Indonesia, Data diolah (2019)

Perkembangan arus kas dan tingkat likuidtas pada lembaga pembiayaan tahun 2013-2017 adalah sebagai berikut :

Rata-rata kas bersih yang diperoleh dari aktivitas operasi pada lembaga pembiayaan mengalami penurunan sebesar -35,3\% pada tahun 2014.dan mengalami peningkatan yang sangat signifikan sebesar 167,3\% pada tahun 2015.Rata-rata kas bersih yang diperoleh dari 
aktivitas investasi pada lembaga pembiayaan mengalami peningkatan sebesar $12,8 \%$ pada tahun 2015, dan mengalami penurunan tajam sebesar -0,7\%pada tahun 2016, , sedangkan rata-rata arus kas bersih yang diperoleh dari aktivitas pendanaan pada lembaga pembiayaan mengalami kenaikan sebesar 14,4\% pada tahun2014 dan mengalami penurunan sebesar 133,6\%.pada tahun 2017.

Pada tahun 2014 tingkat likuiditas yang diukur dengan current ratio pada lembaga pembiayaan mengalami peningkatan sebesar 3,4\% Namun pada tahun 2015 terjadi penurunan current ratio dari perusahaan lembaga pembiayaan sebesar $-40,9 \%$ Pada tahun 2016 dan 2017 perkembangan current rasio sebesar 8,2\% dan 7,7\%.

\section{Uji Statistik}

\section{Pemilihan Model Terbaik}

Pemilihan Model menggunakan Uji Lagrange Multiplier (LM) Nilai probabilitas BreuschPagan (BP) sebesar $0.0000<0.05$ maka model yang cocok dalam penelitian ini adalah Random Effect Model

\section{Uji Asumsi Klasik}

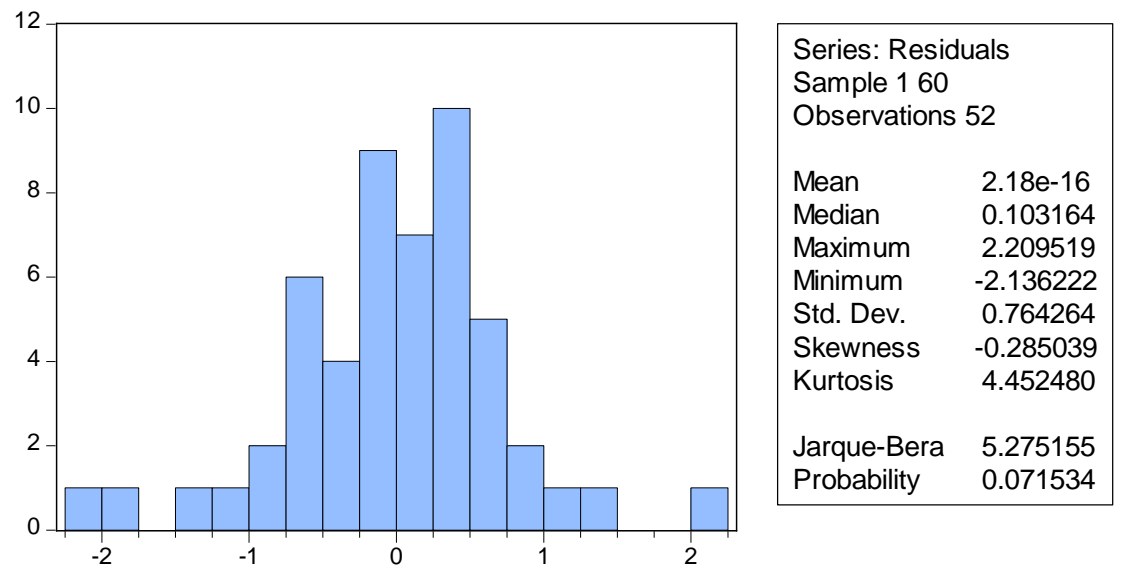

Gambar 3

Hasil Uji Normalitas

Sumber : Data diolah(2019)

Berdasarkan hasil diatas terlihat bahwa nilai probability Jarque Berra sebesar 0,0715 berada diatas nilai 0,05 maka dengan demikian dapat disimpulkan bahwa data dari variabel penelitian ini telah terdistribusi normal.

\section{Tabel 2}

Uji Heteroskedastisitas

\begin{tabular}{llll}
\hline$\square$ Heteroskedasticity Test: White & & \\
\hline F-statistic & 2.919087 & Prob. F(5,46) & 0.0227 \\
Obs*R-squared & 12.52508 & Prob. Chi-Square(5) & 0.0483 \\
Scaled explained & 19.19849 & Prob. Chi-Square(5) & 0.0018 \\
SS & & & \\
\hline
\end{tabular}

Sumber : Data diolah(2019)

Dari tabel 2 diatas dapat dilihat bahwa pengujian heteroskedastisitas dapat dilihat bahwa probability Obs*R-square $=0,0483$ atau lebih besar dari 0,05. sehingga dapat disimpulkan 
data dalam variabel penelitian ini tidak terdapat heteroskedastisitas pada model penelitian ini.

Tabel 3

Uji Autokorelasi

\begin{tabular}{lrll}
\hline \hline \multicolumn{4}{c}{ Effects Specification } \\
Cross-section fixed (dummy variables) & & \\
& & & \\
R-squared & 0.785247 & Mean dependent var & 8.527833 \\
Adjusted R-squared & 0.718435 & S.D. dependent var & 21.74939 \\
S.E. of regression & 11.54081 & Akaike info criterion & 7.941974 \\
Sum squared resid & 5993.562 & Schwarz criterion & 8.465560 \\
Log likelihood & -223.2592 & Hannan-Quinn criter. & 8.146777 \\
F-statistic & 11.75309 & Durbin-Watson stat & 2.072351 \\
Prob(F-statistic) & 0.000000 & & \\
& & & \\
\hline
\end{tabular}

Sumber : Data diolah(2019)

Pada uji autokorelasi, dapat diketahui bahwa nilai Durbin Watson sebesar 2,072 Nilai akan dibandingkan dengan nilai tabel Durbin-Watson d Statistic: Significance Point For dl and du AT 0,5 Level of Significance dengan menggunakan nilai signifikansi 5\% jumlah sampel 60 (n) dan jumlah variabel independen $2(\mathrm{k}=2)$, maka dari tabel Durbin-Watson akan diperoleh nilai batas bawah (dl) yaitu 1,514 dan nilai batas atas (du) adalah 1,6518

Bentuk pengujiannya yaitu Du $<\mathrm{D}-\mathrm{W}<4$-Du maka 1,6518 < 2,072 < 2,3482 kesimpulannya adalah tidak terjadi gejala autokorelasi..

\section{Tabel 4}

\section{Hasil Uji Regresi Data Panel dengan Metode Random Effects}

Dependent Variable: $\mathrm{Y}$

Method: Panel EGLS (Cross-section random effects)

Date: 01/12/19 Time: 21:57

Sample: 20132017

Periods included: 5

Cross-ctions included: 12

Total panel (balanced) observations: 60

Swamy and Arora estimator of component variances

\begin{tabular}{crrrr}
\hline \hline Variable & Coefficient & Std. Error & t-Statistic & Prob. \\
\hline \hline C & 115.6334 & 26.10085 & 4.430253 & 0.0000 \\
X1 & -7.753326 & 2.713705 & -2.857099 & 0.0060 \\
X2 & 3.002523 & 2.306870 & 1.301557 & 0.1984 \\
X3 & -4.846529 & 0.735109 & -6.592943 & 0.0000 \\
\hline
\end{tabular}

Sumber : Data diolah(2019)

Persamaan regresinya sebagai berikut :

$$
Y=115,63-7,753 X 1+3,002 X 2-4,846 X 3
$$

Besarnya likuiditas nilainya adalah sebesar 115,63, apabila variable independen konstan.Dan apabila setiap peningkatan X1 sebesar 1 satuan, maka akan menurunkan 
likuiditas sebesar 7,753 demikian pula untuk X2 dan X3 dapat disesuaikan dengan tabel diatas.

Tabel 5

Hasil Koefisien Determinasi Data Panel dengan Metode Random Effects

\section{Weighted Statistics}

$\begin{array}{llll}\text { R-squared } & 0.741339 & \text { Mean dependent var } & 8.363364 \\ \text { Adjusted R-squared } & 0.727482 & \text { S.D. dependent var } & 21.69987 \\ \text { S.E. of regression } & 11.32804 & \text { Sum squared resid } & 7186.167 \\ \text { F-statistic } & 53.49986 & \text { Durbin-Watson stat } & 1.726853 \\ \text { Prob(F-statistic) } & 0.000000 & & \end{array}$

Sumber : Data diolah(2019)

Nilai Adjust $R$ Square 0,727 menunjukkan bahwa variabel terikat tingkat likuiditas dapat dijelaskan variabel bebas yang terdiri dari arus kas yang berasal dari operasi, Arus kas yang berasal dari investasi dan arus kas yang berasal dari pendanaan sebesar 72,7\%. Sedangkan sisanya sebesar 26,3\% lainnya dipengaruhi faktor lain diluar model regresi tersebut.

Hasil Uji t Statistik dalam penelitian ini adalah sebagai berikut:

Tabel 6

Hasil Uji t (Parsial)

\begin{tabular}{crrrr}
\hline \hline Variable & Coefficient & Std. Error & t-Statistic & Prob. \\
C & 115.6334 & 26.10085 & 4.430253 & 0.0000 \\
X1 & -7.753326 & 2.713705 & -2.857099 & 0.0060 \\
X2 & 3.002523 & 2.306870 & 1.301557 & 0.1984 \\
X3 & -4.846529 & 0.735109 & -6.592943 & 0.0000 \\
\hline
\end{tabular}

Sumber : Data diolah(2019)

Diketahui bahwa t-hitung untuk X1 $(-2,857)>$ t-tabel $(-2,001)$, maka Ho ditolak dan Ha diterima artinya arus kas yang berasal dari operasi berpengaruh signifikan terhadap likuiditas. Diketahui bahwa t-hitung untuk X2 $(1,301)<\mathrm{t}$-tabel $(2,001)$, maka Ho diterima dan Ha ditolak artinya arus kas yang berasal dari investasi tidak berpengaruh signifikan terhadap likuiditas. Diketahui bahwa -t-hitung untuk X3 $(-6,592)>-t$-tabel $(-2,001)$, maka Ho ditolak dan Ha diterima artinya arus kas yang berasal dari pendanaan berpengaruh signifikan terhadap likuiditas.

\section{Tabel 7}

Hasil Uji F (Simultan)

\begin{tabular}{lclll}
\hline & Weighted Statistics & \\
\hline & & & \\
R-squared & 0.741339 & Mean dependent var & 8.363364 \\
Adjusted R-squared & 0.727482 & S.D. dependent var & 21.69987 \\
S.E. of regression & 11.32804 & Sum squared resid & 7186.167 \\
F-statistic & 53.49986 & Durbin-Watson stat & 1.726853 \\
Prob(F-statistic) & 0.000000 & & \\
& & &
\end{tabular}

Sumber : Data diolah(2019) 
Dengan membandingkan nilai F-hitung dengan F-tabel adalah F-hitung > F-tabel (53,49 > 3,29 ) dan probability sebesar $0,000<0,05$, maka Ho ditolak dan Ha diterima yang berarti arus kas yang berasal dari operasi, arus kas yang berasal dari investasi dan arus kas yang berasal dari pendanaan berpengaruh signifikan terhadap tingkat likuiditas.

Hasil penelitian ini sejalan dengan penelitian sebelumnya seperti yang dikemukakan oleh H.M Kirnasari (2011) dimana menyimpulkan bahwa arus kas dari aktivitas operasi,aktivitas investasi dan pendanaan secara simultan berpengaruh signifikan terhadap likuiditas perusahaan.

\section{SIMPULAN}

Berdasarkan hasil uji t, arus kas yang berasal dari operasi dan pendanaan berpengaruh signifikan terhadap likuiditas pada lembaga pembiayaan tahun 2013-2017,sedangkan arus kas yang berasal dari investasi tidak berpengaruh signifikan terhadap likuiditas pada lembaga pembiayaan tahun 2013-2017. Secara simultan arus kas yang berasal dari operasi, arus kas yang berasal dari investasi dan arus kas yang berasal dari pendanaan berpengaruh signifikan terhadap tingkat likuiditas pada lembaga pembiayaan tahun 2013-2017.

\section{DAFTAR PUSTAKA}

Hanafi, Mamduh M, dan Abdul Halim. (2012). Analisis Laporan Keuangan, Edisi Keempat. Yogyakarta: UPP STIM YKPN.

HM.Kirnasari(2011),Pengaruh Arus Kas Terhadap Likuiditas Industri Barang Konsumsi Yang Terdaftar Di Bursa Efek Indonesia 2009 - 2011.,Universitas Negeri Surabaya

Ikatan Akuntan Indonesia. (2013). Exposure Draft Pernyataan Standar Akuntansi Keuangan, Penyajian Laporan Keuangan

Mardiyanto, Handono . (2009). Intisari Manajemen Keuangan: Teori, Soal dan Jawaban. Jakarta: Grasindo.

Nurmiati (2016),Pengaruh Arus Kas Operasi Terhadap Likuiditas Perusahaan Farmasi Yang Terdaftar Di Bursa Efek Indonesia 2014 - 2016 ,Universitas Negeri Makasar

S.Munawir. (2004). Analisis Laporan Keuangan, Edisi Ke-4. Yohyakarta : Liberty.

Stice, Earl K, James D Stice dan Fred Skousen. (2009).Akuntansi Keuangan Menengah, Edisi 16, Buku 2.Edisi Bahasa Indonesia. Terjemah : Ali Akbar. Jakarta : PT. Salemba Empat

Sugiyono. (2012). Metode Penelitian Kuantitatif Kualitatif dan R\&D. Bandung: Alfabeta

Utami,Desi Sri (2013) ,Pengaruh Arus Kas Terhadap Tingkat Likuiditas Keuangan Perusahaan PT.PLN (Persero) 2002 - 2011,Universitas Pendidikan Indonesia

Yogantara, Anggia.(2010). Pengaruh laporan arus kas terhadap tingkat likuiditas (Studi kasus pada perusahaan PT. TDP yang bergerak di bidang industri teksil). Skripsi Universitas Widyatama. 